Historic, Archive Document

Do not assume content reflects current scientific knowledge, policies, or practices. 



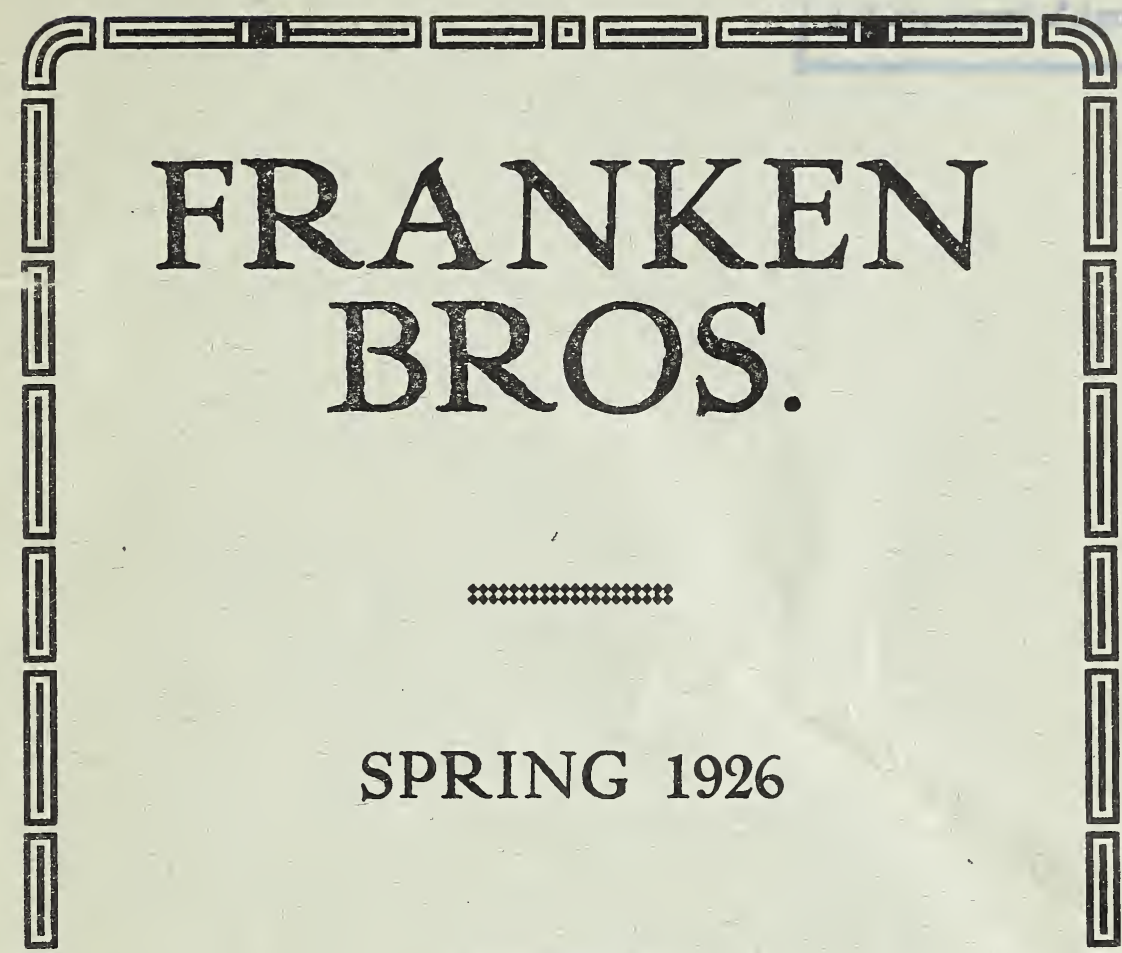

[1]

1

Summer Flowering Bulbs

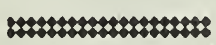

$$
\begin{gathered}
\text { and } \\
\text { Hardy Perennials }
\end{gathered}
$$

DEERFIELD, ILLINOIS

Telephone 241 


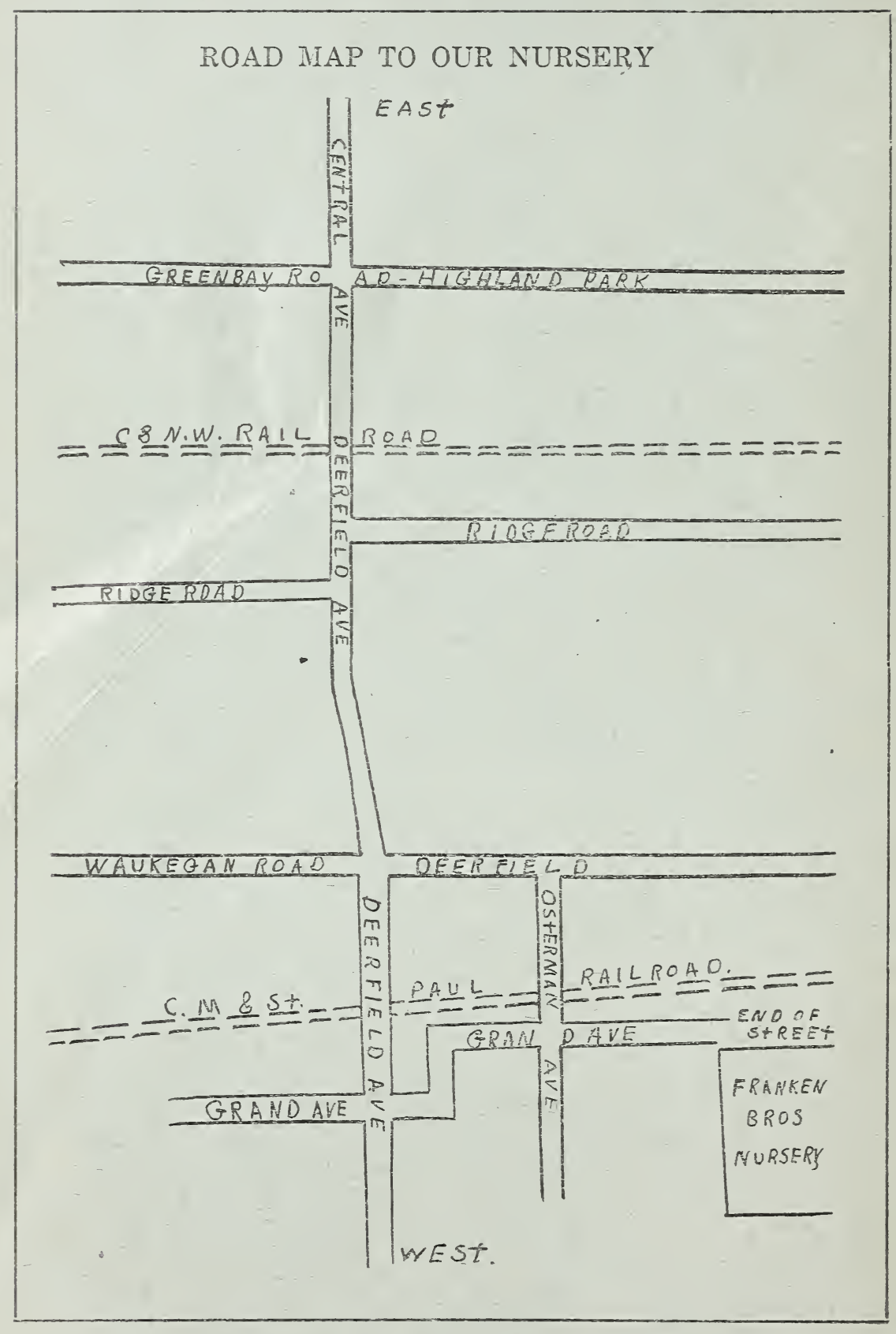




\section{Dahlias}

Our Dahlias are dormant field-grown Tubers. These flowers are becoming more popular every year. They can be set out as soon as the danger of frost is over until July, and taken up after the tops have been cut down by the frost as they are not hardy. They should be kept in a cool place during the winter.

\section{PEONY-FLOWERING DAHLIAS}

These have large loose petaled flowers showing their centers and are borne on strong stems.

California. Rich lemon yellow. Very free flowering. Per

each doz.

Copper. Very unique shade of copper, shading to bronze. Attractive

Goliath. Very large rich scarlet

H. J. Lovink. A beautiful shade of mauve.

Hortanulus Budde. Rich rosy scarlet. Free-blooming ….......... $\quad .40 \quad 4.00$

La Riante. Deep lavender-pink. Curled and twisted................... $\quad .35 \quad 3.50$

Latona. A pale shade of yellow shaded buff and lavender. Very free flowering.

Oregon Beauty. A beautiful shade of Oriental red. Extra large and fine.

Queen Wilhelmina. Pure white. Large and fine.

$.50 \quad 5.00$

Salvator. Deep rose-pink. A dwarf plant but produces flowers on long stems.

\section{CACTUS DAHLIAS}

The petals of this type are long, narrow and incurved, sometimes twisted. They are very attractive and are good bloomers.

Aurore. Bright orange red. Erect grower and free bloomer.... .35

Countess of Lonsdale. Charming blend of salmon-pink and amber. Free-flowering.

Eureka. Velvety violet purple.

Else. Yellow shaded amber.

Golden Gem. Lovely golden yellow.

J. H. Jackson. Deep velvety maroon. The largest and finest dark cactus Dahlia.

Kriemhilde. Soft pink shading to white at the center. Very beautiful.

Mrs. Mace. A very delicate shade of pink.

Rheinkonig. Pure white. A lovely flower.

Pink Pearl. Lilac-pink shading deeper towards the center........ $\quad .30 \quad 3.00$

\section{DECORATIVE DAHLIAS}

A large flowering type with broad compact petals, some slightly incurved. Arabian. Pure tan, delicately splashed with white. Odd and attractive. 


\section{DECORATIVE DAHLIAS-(Continued)}

\begin{tabular}{|c|c|}
\hline & each \\
\hline Delice. A warm shade of pink flushed with a little white............. & .30 \\
\hline $\begin{array}{l}\text { Dr. Thurman. Beautiful shade of yellow shaded with copper.... } \\
\text { Jeane Charmet. Exquisite shade of lilac-pink. Large and beau- }\end{array}$ & .75 \\
\hline tiful. & .40 \\
\hline 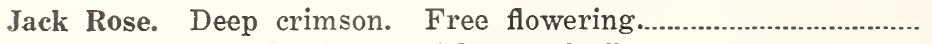 & .25 \\
\hline 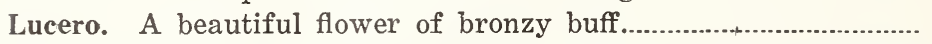 & .60 \\
\hline $\begin{array}{c}\text { Mina Burgle. Beautiful deep glowing crimson. Extra free flow- } \\
\text { ering. }\end{array}$ & .50 \\
\hline Minnie McCullough. A lovely flower of pure bronze..................... & .40 \\
\hline $\begin{array}{l}\text { Perle de Lyon. Pure white. Fringed petals........................................ A glowing orange. One of the } \\
\text { Souvenir de Gustave Douzon. A }\end{array}$ & .25 \\
\hline largest Dahlias grown. & .50 \\
\hline 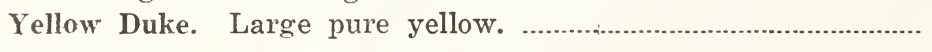 & .40 \\
\hline
\end{tabular}

\section{SHOW DAHLIAS}

This type of Dahlias are very double and globular in form, their petals being slightly incurved. Very desirable.

A. D. Livoni. The most perfect shaped Dahlia. Soft pink. Fine bloomer.

Arabella. Sulphur yellow overlaid with pink.

Augus Megar. The finest lavender purple show Dahlia. A tall and sturdy grower.

Cuban Giant. Very large showy maroon.

Dee-lighted. Pure white. Large and fine.

Dorothy Peacock. Beautiful clear live pink. Free flowering...

Elsie Davidson. Deep golden yellow. Free flowering and beautiful.

Imperial. Deep purplish maroon.

Maude Adams. Snowy white effectively overlaid with delicate pink.

Storm King. Very large pure white flowers borne on long stems

\section{SINGLE DAHLIAS}

This type resembles the cosmos, having a single row of petals and an anemone-like center. Very attractive as a cut flower.

Auburn Beauty. Pure waxy white.

Blanche. Pale yellow faintly tipped pink. One of the most delicate colors.

Empress. A lovely shade of deep rose pink.

St. George. Clear canary yellow. Exceptionally showy............... $\quad .30$ 


\section{POMPOM DAHLIAS}

Dwarf growing plants with small firm flowers borne on long stems. Fine for bedding or cutting because of their free flowering habits.

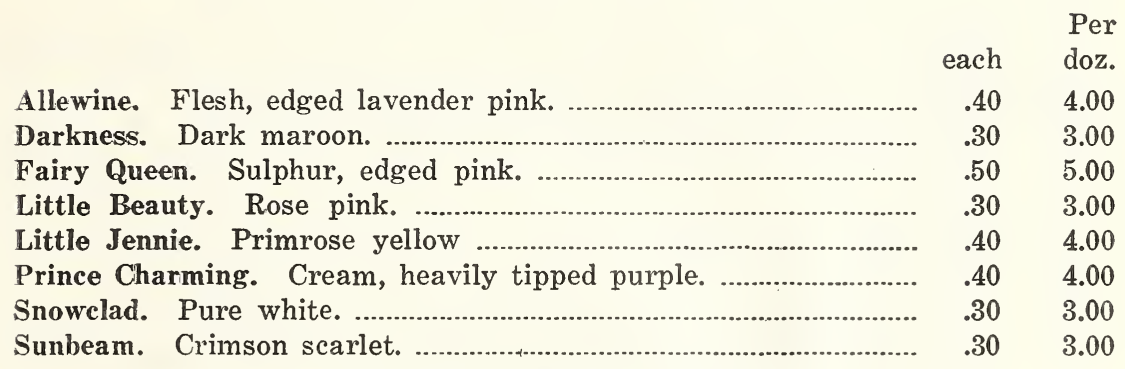

\section{COLLARETTE DAHLIAS}

Flowers similar in form to the Single Dahlias, having one row of petals with anemone-like center, but with a row or collarette of short petals. Very attractive.

Achievement. Clear, velvety maroon with waxy white collarette overlaid with pinkish crimson.

Liebesfeur. Sulphur yellow tinted orange-red with sulphur collarette.

$.30 \quad 3.00$

$.35 \quad 3.50$

Maurice Rivorie. Gorgeous rich crimson with lovely snow-white collarette.

Renee-Gerard. Clear purple guard petals with pure white collarette.

\section{GLADIOLI}

Flowers well known to all, producing graceful spikes valuable for both house and garden decoration. The buds will open finely in the house. Every home should have some of these lovely flowers. Plant as soon as danger of frost is over and continue doing so at intervals of two or three weeks up to July. This gives you a succession of bloom. Bulbs should be taken up in fall after tops have been cut down by frost and kept in a cool place for the winter.

\begin{tabular}{|c|c|}
\hline $\begin{array}{l}\text { Per } \\
\text { doz. }\end{array}$ & $\begin{array}{l}\mathrm{Pe} \\
100\end{array}$ \\
\hline .50 & 3.50 \\
\hline .70 & 5.00 \\
\hline 1.20 & $9.0 \mathrm{c}$ \\
\hline 1.40 & 10.00 \\
\hline 1.00 & 7.0 \\
\hline & \\
\hline
\end{tabular}

America. Exquisite lavender pink. Large and fine. 


\section{GLADIOLI-(Continued)}

$\begin{array}{ll}\text { Per } & \text { Per } \\ \text { doz. } & 100\end{array}$

Golden Measure. Fine dark golden yellow. The best of the yellows.

Gretchen Zang. A lovely flower of a most pleasing shade of geranium pink with carmine markings in throat

Halley. Large flowers of a beautiful salmon-pink. An early variety.

Le Marechal Foch. A wonderful gladioli. A little lighter than America but very early.

Louise. Very beautiful clear pure lavender with small blotch of velvety purplish red towards the center. A very fine variety which greatly resembles the orchid.

Mary Fennell. Beautiful light pinkish lavender. Lower petals penciled primrose yellow. A lovely flower on a tall slender spike.

Mr. Marks. Beautiful shade of lavender blue with darker throat.

Mrs. Francis King. A beautiful shade of flaming pink, very popular.

Mrs. Frank Pendleton. Exquisite salmon pink with blood-red blotch in throat. Immense blooms.

Niagara. Clear nankeen yellow. Light crimson penciling in throat.

Panama. Lovely shade of pure pink. Very large and fine.........

Peace. Pure white with lilac feathering on lower petals...

Prince of Wales. Beautiful light salmon shaded orange..

Red Emperor. A pure deep scarlet. Immense flowers on a tall stem. Very handsome.

$.80 \quad 6.00$

1910 Rose. Very large flower of pure rose-pink. A beautiful variety.

Schwaben. Pure canary yellow shading to sulphur. Throat delicately marked with wine.

War. Deep blood red shaded blackish crimson. Very striking. $1.10 \quad 8.00$

White Giant. Very large pure white. As yet have seen none so pure as this. Very handsome.

Wilbrink. Flesh pink with creamy blotch on lower petals. Very beautiful.

Mixed. A mixture of good colors and flowers.

$.50 \quad 3.50$

\section{PRIMILINUS GLADIOLI}

A new race of Gladioli. Exquisite colors such as terracotta, bronze, copper, rose, pink, saffron, apricot, buff, salmon and a few lavenders and whites. Their flowers are so dainty that they are indispensable for decoration. They flower a little earlier and are also valuable for forcing. 


\section{PRIMILINUS GLADIOLI-(Continued)}

Per Per

doz. $\quad 100$

Alice Tiplady. A beautiful saffron yellow shaded orange. A color unlike any other.

$1.20 \quad 9.00$

$1.10 \quad 8.00$

$1.00 \quad 7.00$

Capello. Bright fiery orange red. Very large and fine.

$1.40 \quad 10.00$ and lovely.

A charming shade of rose pink. Very tall

Golden Gate. Tall and vigorous. Lovely golden yellow ruffled petals.

$1.10 \quad 8.00$

$1.60 \quad 12.00$

Jewell. Light salmon pink with golden throat. A real jewel..... rose. Tall and early.

$1.20 \quad 9.00$

$1.40 \quad 10.00$

Roanoke. Soft canary yellow. Free flowering.

$1.00 \quad 7.00$

$.55 \quad 4.00$

Mixed. Delicate soft pastel shades.

\section{HYACINTHS CANDICANS}

Per Per

doz. $\quad 100$

Free Growing Summer Flowering Hyacinth. Large white bell shaped flowers on spikes three to four feet.

$1.10 \quad 8.00$

\section{TUBEROSES}

Spikes of white flowers easily recognized by their exquisite fragrance.

Dwarf Pearl. Double. Mammoth Bulbs. Blooming in July...... Per Per

doz. 100

Mexican Everblooming. Single. Tall spikes beginning to bloom in July.

$1.10 \quad 8.00$

$.80 \quad 6.00$

\section{Hardy Lilies}

Auratum. (Gold Banded Lily of Japan). White, gold and

Per Per

doz. 100 crimson. The largest and most beautiful garden Lily. They bloom in July and August. Mammoth Bulbs.

Speciosum Rubrum. The same habits as Auratum. Rosywhite, rayed and spotted with crimson. Mammoth Bulbs. 


\section{IRIS GERMANICA (German Iris)}

The German Iris is perfectly hardy and grows luxuriantly everywhere, particularly if in a dry and sunny location. Its spikes of flowers are fragrant and fine for cutting. If cut when the lower buds show color they will open finely in the house. Be particular in planting to barely cover the Rhizomes or large fleshy roots. The petals that stand skyward are called the Standards and the ones that hang so artistically are called Falls. These lovely flowers bloom in May and June.

Our list includes many varieties of recent introduction.

$\begin{array}{ccc} & \text { Per } & \text { Per } \\ \text { each } & \text { doz. } & 100\end{array}$

Alcazar. Standards light bluish violet; falls deep purple with bronze veined throat. A very striking variety.

Arnols. Standards beautiful rosy bronze; falls rich velvety purple. A very handsome flower.

Albert Victor. Standards soft blue; falls a beautiful lavender. A large and beautiful variety.

Canary Bird. (Flavescens). A very delicate shade of canary yellow. A fine flower for cutting and delightfully fragrant.

Caprice. Standards rosy-red; falls deeper. Very handsome.

Celeste. Standards and falls a delicate azure blue. A very beautiful color.

Eldorado. Standards, bronze shaded yellow. Falls violet-purple, edged yellow. Distinct and rich color.....

Florentina Alba. Standards and falls creamy white flushed lavender. Very fragrant and early...

15.00

Fairy. Standards and falls pure white suffused with a most pleasing shade of soft blue. One of the most fragrant and fine for cutting.

Gertrude. Standards and falls deep lavender blue. Very large and fragrant

Her Majesty. Standards lovely rose-pink; falls a deeper shade tinged dark crimson. A beautiful variety....

Hector. Standards soft clouded yellow; falls velvety crimson black. Very showy

Iris King. Standards clear lemon yellow; falls rich maroon bordered yellow. Large flowers and very tall

Jacquisiana. Standards bright copper-crimson; falls rich maroon. A very distinct and beautiful flower.....

James Boyd. Standards large broad incurved, forming a large dome shaped center of light blue; falls deep violet edged lighter. A well expanded flower

Kochii. (Atropurpurea). Standards and falls a rich dark purple. A very handsome variety. 


\section{GERMAN IRIS-(Continued)}

Lohengrin. Standards and falls a uniform shade of pink silvery mauve. A beautiful color.

$\begin{array}{ccc} & \text { Per } & \text { Per } \\ \text { each } & \text { doz. } & 100\end{array}$

$.25 \quad 2.50 \quad 18.00$

Loreley. Standards light yellow; falls ultramarine blue bordered cream. Very good bloomer

Lygia. Standards pale mauve; falls pale mauve feathered dark mauve. An artistic flower

$3.50 \quad 25.00$

Madame Chereau. Standards and falls pure white, daintily bordered with clear blue. A very distinct and delicate color

18.00

Mary Garden. Standards pale yellow flushed lavender; long drooping falls creamy white dotted and veined maroon. Stigmas clear yellow

Massasoit. Standards and falls a very distinct shade of metallic Venetian blue. Very difficult to describe accurately

$\begin{array}{ll}.50 & 5.00 \quad 38.00\end{array}$

Monsignor. Standards rich satiny violet; falls velvetycrimson purple with lighter margin. An exceptionally large flower

Mrs. II. Darwin. Standards and falls clear satiny white slightly netted at the base with lavender. Very free-flowering and lovely

Niebelungen. Standards fawn yellow; falls violet purple with fawn margin. Very handsome.

$\begin{array}{lll}.30 & 3.00 \quad 22.00\end{array}$

Pallida Dalmatica. Popularly regarded as the best of German Irises. Standards and falls immense clear, light lavender blue. Tall and fragrant.

Pallida Odoratissima. Handsome fragrant flowers of light blue

Perfection. Standards light blue; falls dark velvety violet black with orange beard. A bold conspicuous flower

$\begin{array}{lll}.30 & 3.00 \quad 22.00\end{array}$

Princess Victoria Louise. Standards sulphur yellow; falls rich plum bordered cream..................................

Prosper Laugier. Standards fiery bronze; falls velvety ruby purple with orange beard.

$\begin{array}{lll}.30 & 3.00 \quad 22.00\end{array}$

$\begin{array}{lll}.35 & 3.50 \quad 25.00\end{array}$

Purple King. Full rich purple. Very distinct and effective

Queen Alexander. Standards fawn spotted lilac; falls, lilac, reticulated at the base with bronze. Very beautiful

Queen of May. Standards and falls a lovely soft roselilac; almost pink. A very beautiful variety........

Rheine Nixe. Standards pure white and very large; falls deep violet blue with narrow white edge. 


\section{GERMAN IRIS-(Continued)}

$\begin{array}{lllr} & & \begin{array}{c}\text { Per } \\ \text { doz. }\end{array} & \begin{array}{r}\text { Per } \\ 100\end{array} \\ \text { Rose Unigue. Standards and fails deep violet rose.......... } & .40 & 4.00 & 30.00 \\ \text { Sherwin Wright. Standards and falls rich golden yel- } & & & \\ \text { low. Free from markings and shadings. Strong } \\ \text { free grower and most profuse bloomer. A splendid } \\ \text { acquisition }\end{array}$

\section{IRIS SIBERICA-(Siberian Iris)}

A smaller flowering type of Iris than the German Iris. Narrow grassy foliage with blue and white flowers borne on tall stems. Very free flowering and fine for cutting. May-June.

Siberica. Rich violet blue. Early .................................... $.15 \quad 1.50 \quad 10.00$

$\begin{array}{lllll}\text { Orientalis. Rich violet blue. Late ......................................... } & .15 & 1.50 & 10.00\end{array}$

Orientalis Snow Queen. Pure white form of above. Late $\begin{array}{llll}15 & 1.50 & 10.00\end{array}$

\section{IRIS PSEUDACORUS}

Similar in type to the Siberian Iris but may be planted where water habitually stands or in a dry place. May-June.

Yellow Water Flag. Golden yellow.

.15

$1.50 \quad 10.00$

\section{INTERMEDIATE IRIS}

Similar in type to the German Iris but blossoming earlier and with shorter stems. May is their blooming season.

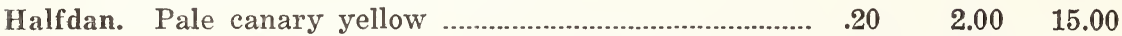

$\begin{array}{llllll}\text { Prince Victor. Standards blue; falls deep violet................ } & .20 & 2.00 & 15.00\end{array}$

$\begin{array}{lllll}\text { Walhalla. Standards pale lavender blue; falls wine red } & .20 & 2.00 & 15.00\end{array}$

\section{DWARF BEARDED IRIS}

Very valuable for planting in front of the taller varieties. Flowers are of the same type as the German Iris but they are very dwarf. Pumila blooms the latter part of April.

$\begin{array}{lllll}\text { Pumila. Standards violet blue; falls deep violet purple } & .15 & 1.50 & 10.00\end{array}$

\section{HEMEROCALLIS (Day Lilies)}

These lovely flowers are favorites for the hardy garden, succeeding everywhere. The tall grasslike foliage is beautiful and the lily-like flowers very effective. The new Hybrids are particularly pleasing.

Citrinna. A lovely variety of a pure lemon yellow, producing very large flowers. The latest of all to bloom. 3-4 feet

Florham. Very beautiful frilled flowers of a soft yellow. June. 2-3 feet 


\section{HEMEROCALLIS-(Day Lilies)-(Continued)}

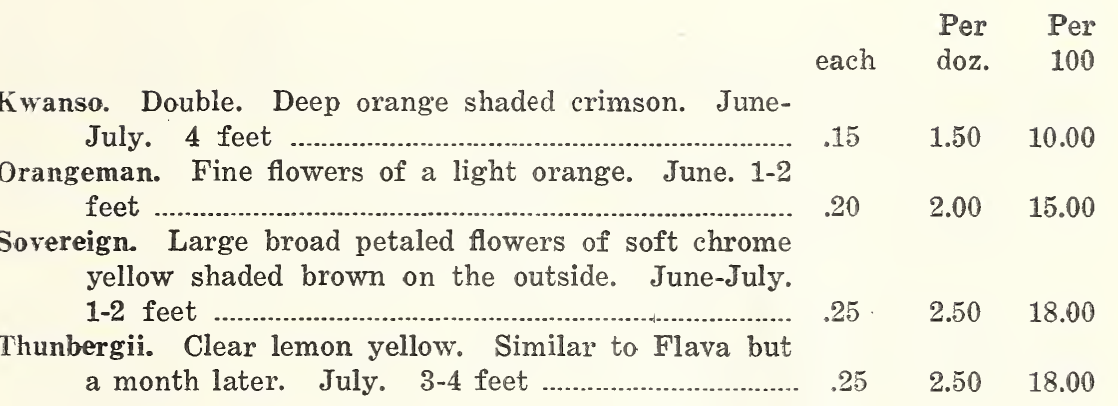

\section{Phlox Decussata}

For large masses of color in late Summer and Autumn, Phlox are unsurpassed. They bloom in July and August, a time when bright colors and masses of bloom are very scarce. They grow about three feet high, with the exception of a few varieties. They require only an ordinary garden cultivation.

Antonin Mercie. Beautiful grayish lilac with pure white center. Very large and attractive.

$\begin{array}{lll} & \text { Per } & \text { Per } \\ \text { each } & \text { doz. } & 100\end{array}$

B. Comte. Rich dark velvety crimson. Large individual flowers

$.25 \quad 2.00 \quad 15.00$

Eclaireau. Bright rosy carmine with a lighter halo.......

Elizabeth Campbell. Light salmon-pink with light center. Very fine

Eugene Danzanvilliers. Lovely soft lilac blue with pure white center. A long compact truss......................

Europa. Pure white with decided crimson-carmine eye. Individual flowers and trusses very large................

Henry Murger. Purest white with a deep rose center. A handsome flower ...................................................

Jeanne d'Arc. Pure white. Late. Exceptionally fine

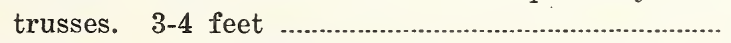

L'Evenement. A very soft tender salmon pink. 2 feet

Lummineaux. Soft rose with a carmine blush center. Very fine

$\begin{array}{lll}.25 & 2.00 \quad 15.00\end{array}$

$\begin{array}{lll}.25 & 2.00 \quad 15.00\end{array}$

$\begin{array}{lll}.35 & 3.50 \quad 25.00\end{array}$

$\begin{array}{lll}.25 & 2.00 \quad 15.00\end{array}$

$\begin{array}{lll}.25 & 2.00 \quad 15.00\end{array}$

$\begin{array}{lll}.25 & 2.00 \quad 15.00\end{array}$

$\begin{array}{lll}.25 & 2.00 \quad 15.00\end{array}$

$\begin{array}{lll}.25 & 2.00 \quad 15.00\end{array}$

$\begin{array}{lll}.25 & 2.00 \quad 15.00\end{array}$

Miss Lingard. Pure white with pale lilac eye. Dark shiny foliage and very free flowering. June until Autumn

Mrs. Jenkins. Immense heads of purest white. Beautiful 


\section{PHLOX DECUSSATA-(Continued)}

\begin{tabular}{|c|c|c|c|}
\hline & each & $\begin{array}{l}\text { Per } \\
\text { doz. }\end{array}$ & $\begin{array}{l}\text { Per } \\
100\end{array}$ \\
\hline Ornament. Clear lilac-rose with darker center.................. & .25 & 2.00 & 15.00 \\
\hline Rheinlander. Beautiful salmon pink with claret eye........ & .25 & 2.00 & 15.00 \\
\hline $\begin{array}{l}\text { Riverton Jewel. Mauve-rose with carmine eye. Im- } \\
\text { mense heads and beautiful free bloomer.................... }\end{array}$ & .25 & 2.00 & 15.00 \\
\hline $\begin{array}{l}\text { R. P. Struthers. Bright rosy red with crimson eye. } \\
\text { Very fine variety }\end{array}$ & .25 & 2.00 & 15.00 \\
\hline $\begin{array}{c}\text { Rosenberg. Rich carmine violet with blood red eye. } \\
\text { Immense heads and individual flowers }\end{array}$ & .25 & 2.00 & 15.00 \\
\hline $\begin{array}{l}\text { Rynstrom. Beautiful shade of clear pink. Immense } \\
\text { heads and individual flowers }\end{array}$ & .25 & 2.00 & 15.00 \\
\hline $\begin{array}{l}\text { Snowbird. Pure white with soft pink eye. Very deli- } \\
\text { cate color }\end{array}$ & .25 & 2.00 & 15.00 \\
\hline 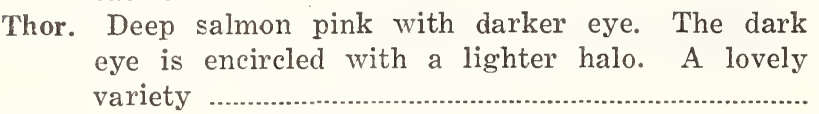 & .25 & 2.00 & 15.00 \\
\hline $\begin{array}{l}\text { Viking. Soft salmon-rose. One of the latest to flower } \\
\text { Wanadis. Lilac-blue with reddish violet eye. A very }\end{array}$ & .25 & 2.00 & 15.00 \\
\hline & .25 & 2.00 & 15.00 \\
\hline $\begin{array}{l}\text { Widar. Violet blue with large pure white center. In- } \\
\text { dividual flowers and trusses very large...................... }\end{array}$ & & 2.00 & 15.00 \\
\hline
\end{tabular}

\section{PHLOX SUBULATA (Moss Pink)}

An early spring-flowering Phlox with moss-like foliage. When in bloom the foliage is completely hidden.

Alba. Pure White

$\begin{array}{lll}.25 & 2.00 \quad 15.00\end{array}$

Lilacina. Light lilac

Rosea. Bright rose-pink

\section{Hardy Perennials}

Achillea. (Milfoil). Very easy border plant growing about two feet high with clusters of flowers the entire summer. Very valuable as a cut flower.

The Pearl. Pure white

Agrostemma. Strong erect plant with silvery foliage. June-July. 2 feet.

Alba. Pure white

Coronaria. Bright crimson

Anchusa Italica. Bushy plant growing from three to five feet throwing branches of forget-me-not like flowers in May and June.

Dropmore Variety. Rich gentian blue 


\section{HARDY PERENNIALS-(Continued)}

Anthemis. (Marguerite). A bushy plant with ferny Per Per each doz. 100 foliage about 15 inches high blooming the entire summer.

Tinctoria. Golden-yellow

Aquilegia. (Columbine). A very pretty plant for all places. They produce spurred flowers on stems one to two feet above the foliage. They are of easy culture and bloom in June. 2-3 feet.

Silver Queen. Pure white

Canadensis. The native red and yellow columbine....

Chrysantha. Golden yellow

$1.80 \quad 13.00$

Coreulea. Blue and white

$2.00 \quad 15.00$

$1.80 \quad 13.00$

Long Spurred Pink Hybrids. Mixed shades of pink $2.00 \quad 15.00$

Aster Hardy. (Michaelmas Daisy). These are very showy late flowering plants having showy flowers during September and October.

Novae Angliae. A beautiful variety giving large branching spikes of lavender-blue Daisy like flowers

Baptisca. (False Indigo). Very attractive pea-shaped flowers in June. The foliage is also sturdy and attractive.

Australis. Dark blue

Boltonia. (False Chamonile). A tall, bushy plant producing hundreds of small single aster-like flowers in late summer and autumn. Their masses of bloom make them very showy.

Asteroides. Pure white. 5-7 feet

Latisquama. Lavender-pink. 4-6 feet

$.20 \quad 1.80 \quad 13.00$

Chrysanthemum. The pure white daisy with the golden center so well known which blooms the entire summer and well into the fall. 2 feet.

Shasta Daisy. Mixed

Shasta, King Edward VII. The same as above except that it has foliage along the stem..

Centurea. A sturdy plant about two feet in height. Blooms resemble the Bachelor Button. July-Sept.

Montana. (Perennial Corn-Flower) violet blue.

$.20 \quad 1.80 \quad 13.00$

Coreopsis. A showy plant with shiny foliage producing daisy-like flowers the entire summer. 2 feet.

Lanceleolata Grandiflora. Golden yellow

Delphinium. (Larkspur). Spikes of lovely flowers commencing to bloom in June. These can be cut back when through blossoming and they will send up another flower but it will not be quite as tall. 


\title{
HARDY PERENNIALS-(Continued)
}

\begin{abstract}
Belladona. Delicate sky-blue. 3-4 feet
Bellamosa. Deep blue form of Belladonna. 3-4 feet

Chinese. Blue. Finely cut foliage, 2 feet................... feet

Gold Medal Hybrids. Various shades of blue. 4 feet

Dianthus Barbatus. (Sweet William). A free flowering Perennial producing in early summer beautiful heads of flowers.

Mixed colors. 1-2 feet

Newport Pink. Salmon-pink. 1-2 feet

Dianthus Plumaris. (Garden Pinks). A pretty border plant with grassy foliage producing sweet clove scented little flowers in May and June. 1 foot.
\end{abstract}

each

Per Per .25

.25

$2.00 \quad 15.00$ $.25 \quad 2.00 \quad 15.00$

$.25 \quad 2.00 \quad 15.00$

Mixed Colors

Echinops Ritro. (Globe Thistle). An interesting plant producing large globular heads of steel blue flowers

Eryngium Planum. (Sea Holly). Ornamental plants about two feet high with varnished like foliage producing steel blue heads in late summer.

$.20 \quad 1.80 \quad 13.00$

Funkia. (Plantain Lily). Lovely border plants with wide leaves overlapping each other and throwing forth spikes of lily-like flowers.

Coerulea. Blue. 2-3 feet

Undulata Variegata. Green and white foliage with lavender lily-like flowers

Gaillardia. (Blanket Flower). A showy plant blooming from June on through the summer. They belong to the daisy family. 2 feet.

Grandiflcra. Center brownish red shading lighter towards the edge with golden edge

Gypsophila. (Baby's Breath). A very beautiful bushy plant blooming in July and August and giving a mist like effect of minute flowers. Fine for bouquets.

Paniculata. Pure white. 2-3 feet

Hibiscus. (Mallow). A good border plant with large lily-like flowers the entire summer. 3-5 feet.

New Giant Red

New Giant Pink

New Giant White

Hollyhocks. Strong garden plants with large cup shaped flowers along the stalk. June. 6-8 feet.

Single. Separate colors 


\section{HARDY PERENNIALS-(Continued)}

Double. Separate colors

Alleghany. Pale pink to red Mixed

Mixed. Single and double. All colors

Lychnis Chalcedonia. An erect growing plant with heads of orange-scarlet flowers in June and July. 2-3 feet

Linum. (Flax). A small plant with fine cut foliage having a spray like appearance with small forgetme-not like flowers all summer. Fine for rockery.

Perene. Medium blue. 1-2 feet

Lupinus. Effective spikes for the hardy garden or border. May and June. 3 feet.

Polyphyllus. Clear blue

Polyphyllus Rosea. Pink.

Polyphyllus. Mixed

Monardo. (Bergamot). Showy plants producing feathery flowers in July and August. 2 feet.

Didy ma Cambridge Scarlet. Brilliant crimson scarlet

Papaver Orientale. (Oriental Poppy). Nothing equals the brilliancy of the poppy in May and June. 2-3 feet.

Oriflame. Orange scarlet

Physotegia. (False Dragon Head). Showy plants somewhat resembling Snap Dragon and flowering in mid-summer. 4 feet.

Virginica. Pink

Virginica Alba. White

Platycoden. (Balloon Flower). Very attractive plants producing star-shaped flowers from July to Oct. 2 feet.

Grandiflora. Deep blue

Grandiflora. Double blue

Pyretheum Hybridum. A beautiful plant with ferm like foliage producing in June a mass of painted daisies and if seed buds are not allowed to form they will flower again. The colors range from pale pink to deep pink but no pure whites or reds. 2 feet.

Mixed

Pyretheum Uliginosum. (Giant Daisy). A tall growing plant producing pure white daisy-like flowers with golden centers in abundance from Aug. to Sept. 3-4 feet

Rudbeckia. Hardy plants of easy culture growing everywhere. .20

$\begin{array}{crr} & \begin{array}{rr}\text { Per } \\ \text { doz. }\end{array} & \begin{array}{r}\text { Per } \\ 100\end{array} \\ .20 & 1.80 & 13.00 \\ .20 & 1.80 & 13.00 \\ .20 & 1.80 & 13.00 \\ & & \\ .20 & 1.80 & 13.00 \\ & & \\ & & \\ .20 & 1.80 & 13.00 \\ & & \\ .25 & 2.00 & 15.00 \\ .25 & 2.00 & 15.00 \\ .25 & 2.00 & 15.00\end{array}$




\section{HARDY PERENNIALS-(Continued)}

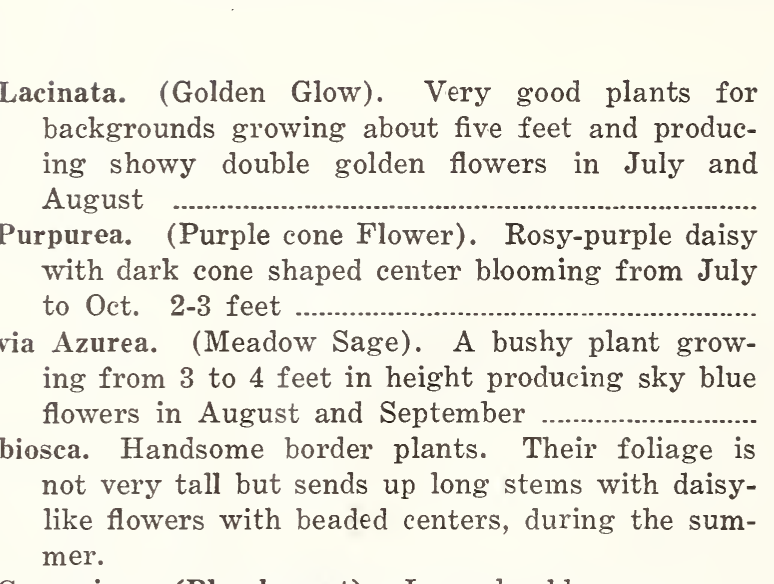

Caucasica. (Blue-bonnet). Lavender blue

Sedum. (Stone-crop). Suitable for the rockery or border with light green foliage and heads of flowers in late summer and fall.

Acre. Golden yellow. Creeping variety .....................

Spectibile. Light rose. 18 inches ................................

Spectibile Brilliant. Amaranth red. 18 inches..........
(Cornflower Aster). A beautiful border plant $\begin{array}{lll} & \text { Per } & \text { Per } \\ \text { each } & \text { doz. } & 100\end{array}$

Stokesia. (Cornflower Aster). A beautiful border plant
producing aster-like flowers from June to Sept. 18 inches.

Cyanea. Lavender-blue

Veronica. (Speedwell). A very sturdy, hardy plant suitable for border or rockery.

Longifolia Subsellis. Spikes of deep blue flowers from July to September. 2 feet

*Yucca Filamantosa. (Thread and Needle plant). Broad hairy sword-like foliage producing strong spikes of creamy bells in June and July. 4-6 feet.

Small size

Medium size

(*Can not be shipped by parcel post.)

\section{Peonies}

In the interest of our customers we do not list our Peonies at this time, although we have a fine lot of choice varieties growing in our field. Peonies start active growth so early in the spring that it is very difficult to dig, pack and ship them without injury, as growth and development will be checked for a year. Fall is the proper time to transplant them. If, however, it is imperative that vacancies in the garden be filled, we fill orders for them if received before active growth begins. Varieties may be selected from our Fall Catalogue of 1925 , and we cordially invite you to visit us during their blooming season. 


\section{SPECIAL NOTICE:}

All persons to whom this catalogue is sent will also receive in May our General Catalogue, which will contain the largest and finest collection of Holland Bulbs for Autumn Delivery which we have ever offered.

We have at our Nursery in our trial grounds a collection of about 500 varieties of Single Early, Double Early, Darwin, Cottage, Breeder and Rembrandt Tulips, and we cordially invite you to visit us during their blooming season.

We have for years supplied our bulbs and plants to many of the large estates in the beautiful suburban towns on the lake, north of Chicago. This fact alone is indicative of the quality of our stock.

\section{TELEPHONE}

We may be conveniently reached by telephone from Chicago and the towns along the "North Shore."

Our number is "Deerfield 241."

\section{RATES}

Six or more bulbs or plants of any one named variety offered in this catalogue will be sold at the dozen rate, 25 or more at the 100 rate, and 250 or more at the 1000 rate. 



\section{INDEX}

\begin{tabular}{|c|c|c|}
\hline Dahlias_Cactus & 1 & Iris-Intermediate …........ 8 \\
\hline " - Collarette & 3 & "-Pseudacorus \\
\hline -Decorative ........ & $1-2$ & $"$-Siberian ............. \\
\hline -Peony Flowering & 1 & Lilies-Hardy \\
\hline -Pompom & 3 & Peonies $\quad 14$ \\
\hline -Show & 2 & Perennials ………10-14 \\
\hline 一Single & 2 & Phlox-Decussata _........ 9-10 \\
\hline Gladioli-Hybrids & $3-4$ & "-Subulata $\quad 10$ \\
\hline " -Primilinus & $4-5$ & Rates ……-15 \\
\hline Hemerocallis _.................. & $8-9$ & Special Notice \\
\hline 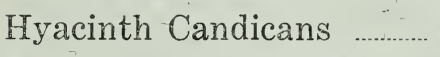 & 5 & Telephone \\
\hline $\begin{array}{l}\text { Iris-Dwarf Bearded } \\
\text { “-Germanica }\end{array}$ & $\begin{array}{l}8 \\
6-8\end{array}$ & $\begin{array}{l}\text { Terms ..... Outside Back Cover } \\
\text { Tuberoses }\end{array}$ \\
\hline
\end{tabular}




\section{Terms of Business}

\section{CONCERNING OUR PRICES}

The prices quoted in this catalogue are for bulbs and plants of the best quality only, true to name and in sound and healthy condition, properly packed and delivered to the Express or Freight office in Deerfield, free of all charges. Express or Freight charges for transportation from Deerfield must, however, be paid by the purchaser.

\section{SHIPPING}

It is our custom to ship our goods by Express as we find the service more satisfactory and, as a rule, cheaper, owing to the size and weight of the packages.

If any customer prefers the Parcel-Post, we will forward small packages in that manner, provided sufficient postage is remitted with the order. Any excess will be returned.

We guarantee our bulbs and roots to be true to name, healthy and in sound condition and strictly first class. We will not, however, be responsible for the failure of any to grow or thrive, as such failure may result from causes wholly beyond our control, such as improper treatment, unfavorable weather, soil or climate. Should any difficulty arise through any fault or mistake of our own we will gladly rectify it. If the purchaser does not accept the goods on these terms, they are at once to be returned and money that has been paid for same will be refunded.

Orders from unknown correspondents must be accompanied by cash or satisfactory references.

We prefer not to receive C. O. D. Orders, but if such are sent they must be accompanied by cash to one-fourth of the value of the goods ordered to insure acceptance.

Money should be sent only by safe methods, preferably Postal or Express Money Orders payable to FRANKEN BROTHERS at DEERFIELD, ILLINOIS, or drafts on Chicago or New York. 